\title{
Evaluation of malignant mesothelioma in central Anatolia: A study of 67 cases
}

\author{
Inci Gulmez PhD ${ }^{1}$, Levent Kart PhD², Hakan Buyukoglan MD ${ }^{1}$, Ozlem Er PhD³, \\ Suleyman Balkanli PhD ${ }^{4}$, Mustafa Ozesmi PhD ${ }^{1}$
}

\begin{abstract}
I Gulmez, L Kart, H Buyukoglan, O Er, S Balkanli, M Ozesmi. Evaluation of malignant mesothelioma in central Anatolia: A study of 67 cases. Can Respir J 2004;11(4):287-290.
\end{abstract}

BACKROUND: Malignant mesothelioma (MM) is a fatal neoplasm which frequently results from exposure to asbestos or erionite. METHOD: Sixty-seven patients with MM were seen between 1990 and 2001. Their clinical and radiological features, as well as the therapy, were retrospectively evaluated.

RESULTS: In 51 patients (76.1\%), the MM was confined to the pleura, in 14 patients it was exclusively peritoneal and in two patients, it involved both areas. Of the 67 cases, 35 (52.2\%) were women. The mean $( \pm \mathrm{SD})$ age for all cases was $57.6 \pm 11.5$ years. Dyspnea $(67.2 \%)$, cough $(55.2 \%)$ and chest pain $(50.7 \%)$ were the most frequent symptoms of onset. Pleural effusion (92.4\%) was the most common chest $\mathrm{x}$-ray finding, whereas pleural effusion $(60.8 \%)$, pleural nodules (34.7\%) and pleural thickening $(34.7 \%)$ were the most common computed tomography findings in pleural MM patients. The histological subtypes of MM were determined as epithelial in 60 patients (89.5\%), sarcomatous in four patients $(5.9 \%)$ and mixed in three patients (4.4\%). Although $50.7 \%$ and $25.4 \%$ of the cases were exposed to erionite and asbestos, respectively, $23.9 \%$ of the cases recalled no exposure to asbestos or erionite. Exposures were environmental as opposed to occupational. Thirty-five patients $(52.2 \%)$ were administered chemotherapy, and follow-up data were available for 22 patients. For these patients, the two-year survival rate was $22 \%$ and the twoyear progression-free interval was $15.7 \%$. There were no differences between patients with asbestos and erionite exposure

CONCLUSION: MM should be considered when exudative pleural effusion is detected in a patient who has been exposed to asbestos or erionite. MM is a major public health problem in parts of Turkey and compulsory environmental control of fibrous mineral should be considered.

\section{L'évaluation du mésothéliome malin en Anatolie centrale : Une étude de 67 cas}

HISTORIQUE : Le mésothéliome malin (MM) est un néoplasme fatal qui découle souvent de l'exposition à l'amiante ou à l'érionite. MÉTHODOLOGIE : Soixante-sept patients atteints de MM ont été observés entre 1990 et 2001. Leurs caractéristiques cliniques et radiologiques, ainsi que leur traitement, ont fait l'objet d'une évaluation rétrospective. RÉSULTATS : Le MM était confiné à la plèvre chez 51 patients (76,1 \%), au péritoine chez 14 patients, et il touchait les deux foyers chez deux patients. Des 67 cas , 35 (52,2\%) étaient des femmes. Lầge moyen ( \pm ÉT)

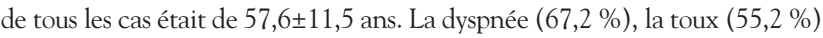
et les douleurs thoraciques $(50,7 \%)$ étaient les symptômes d'apparition les plus fréquents. La radiographie thoracique la plus observée était une effusion pleurale $(92,4 \%)$, tandis qu'à la tomodensitométrie, on observait surtout une effusion pleurale $(60,8 \%)$, des nodules pleuraux $(34,7 \%)$ et un épaississement pleural $(34,7 \%)$ chez les patients atteints de MM de la plèvre. Les sous-types histologiques de MM étaient de nature épithéliale chez 60 patients $(89,5 \%)$, de nature sarcomateuse chez quatre patients $(5,9 \%)$ et de nature mixte chez trois patients $(4,4 \%)$. Bien que $50,7 \%$ et que $25,4 \%$ des cas avaient été exposés à l'érionite et à l'amiante, respectivement, $23,9 \%$ des cas ne se rappelaient pas y avoir été exposés. L'exposition était environnementale plutôt qu'industrielle. Trente-cinq patients $(52,2 \%)$ ont subi une chimiothérapie, et des données de suivi étaient disponibles à l'égard de 22 patients. Dans leur cas, le taux de survie au bout de deux ans s'élevait à $22 \%$, et l'intervalle de deux ans sans progression, à $15,7 \%$. On ne remarquait aucune différence entre les patients exposés à l'amiante et ceux exposés à l'érionite.

CONCLUSION : Le MM devrait être envisagé à la détection d'une effusion pleurale exsudative chez un patient qui a été exposé à l'amiante ou à l'érionite. Le MM est un grave trouble de santé publique dans certaines régions de la Turquie, et un contrôle environnemental obligatoire du minéral fibreux devrait y être envisagé.

Key Words: Asbestos; Erionite; Malignant mesothelioma; Turkey

$\mathrm{M}$ alignant mesothelioma (MM) is thought to originate from the mesothelial cells lining the pleural, peritoneal and pericardial cavities (1). In Turkey, this disease is common in people born or living in certain villages in the central and the southeastern regions of the country $(2,3)$.

Pleural MM is caused by environmental and occupational exposure to asbestos or erionite (4). Erionite, a natural fibrous zeolite that can be found in volcanic tufts, is an environmental contaminant in the Cappadocia region of Central Anatolia (5). Volcanic rocks containing erionite are common in three villages - Karain, Tuzkoy and Sarihidir - which are built on and into these volcanic rocks. Although fibre levels are low, high proportions of erionite have been detected in airborne dust samples collected from these villages $(2,6)$. Epidemiological

${ }^{1}$ Department of Pulmonary Medicine, Medical Faculty, Kayseri Erciyes University, Kayseri; ${ }^{2}$ Department of Pulmonary Medicine,

Medical Faculty, Zonguldak Karaelmas University, Zonguldak; Departments of ${ }^{3}$ Oncology and ${ }^{4}$ Pathology, Medical Faculty, Kayseri Erciyes University, Kayseri, Turkey

Correspondence: Dr Levent Kart, Assistant Professor, Department of Pulmonary Medicine, Medical Faculty, Zonguldak Karaelmas University, 67600 Zonguldak, Turkey. Telephone +90-372-2610169, fax +90-372-2610155, e-mail kartlevent@yahoo.co.uk or

leventkart@karaelmas.edu.tr 
TABLE 1

Patient distribution according to history of exposure to types of mineral fibres

\begin{tabular}{lcc}
\hline Mineral fibre & Male patients $(\mathbf{n}=\mathbf{3 2})(\%)$ & Female patients $(\mathbf{n}=\mathbf{3 5})(\%)$ \\
\hline Erionite $(\mathrm{n}=34)$ & $16(50)$ & $18(51)$ \\
Asbestos $(\mathrm{n}=17)$ & $8(25)$ & $9(26)$ \\
None $(\mathrm{n}=16)$ & $8(25)$ & $8(22.8)$ \\
\hline
\end{tabular}

studies in these villages have shown that the incidence of MM is 1000 times higher than the reported general population incidence in Canada $(7,8)$.

There are many asbestos deposits in some rural parts of Central and Eastern Anatolia. The types of asbestos found in most of these regions are either tremolite or chrysolite, which have no economic value (1). However, villagers use asbestoscontaminated soil (white soil) as a whitewash or plaster material (white stucco), as a substitute for baby powder and on roofs for insulation and prevention of water leakage, etc. Whitewashing walls and floors may be repeated every year. Thus, householders are repeatedly exposed to asbestos fibres in their environment from an early age (9).

Kayseri, where Kayseri Erciyes University is located, is approximately $100 \mathrm{~km}$ from the erionite villages and $150 \mathrm{~km}$ from the asbestos regions in Central Anatolia. The university hospital serves these populations, which largely consist of farmers. In the present study, we evaluated clinical, radiological and laboratory findings of MM, as well as our therapeutic approach for these patients.

\section{PATIENTS AND METHODS}

A thorough review of patient records at the Erciyes University Department of Pulmonary Medicine disclosed that 67 patients with MM were seen between 1990 and 2001.

Clinical information, including age, sex, birthplace, history of occupational and environmental exposure to mineral fibres or chemicals, previous irradiation, character of symptoms and clinical findings at presentation, was obtained from the patients' records. General malaise, weight loss and appetite were accepted as constitutional symptoms.

The diagnoses were made on the basis of pleural and peritoneal tissue obtained by thoracoscopic or laparoscopic needle biopsy, cytological examination, or biopsy of subcutaneous nodules or lymph nodes. The pathological diagnoses were made on the basis of ordinary tissue sections stained with hematoxylin and eosin; further immunohistochemical stains were used as needed. Depending on the differential diagnosis, additional markers, such as thyroid transcription factor-1, carcinoembryonic antigen, CD34, were applied. Pathological subtyping of mesothelioma was obtained from the pathology records. In the majority of cases, there was no information about pathological tumour-nodemetastasis staging.

Chest x-ray, computed tomography (CT), ultrasonography (US) and laboratory findings were recorded. Chest radiographs were assessed by three chest physicians, and differences were resolved by consensus. CT scans of the chest, when available, were evaluated by the same physicians, who were unaware of either the plain chest $\mathrm{x}$-ray or clinical findings. US findings at the time of presentation were also extracted from the patient records.
TABLE 2

Plain chest $x$-ray findings in the malignant pleural mesothelioma patients $(n=53)$

\begin{tabular}{lc}
\hline Chest x-ray finding & $\mathbf{n}(\%)$ \\
\hline Unilateral pleural fluid & $49(92.4)$ \\
Pleural calcification & $5(9.4)$ \\
Pleural thickening & $4(7.5)$ \\
Bilateral pleural fluid & $4(7.5)$ \\
Pleural-based lobulated mass & $2(3.7)$ \\
Normal & $8(15.0)$ \\
\hline
\end{tabular}

Chemotherapy was given to 35 patients and survival data were acquired for 22 of these patients from patient records or local authorities.

Statistical analyses were performed using the Statistical Package for the Social Sciences (SPSS) software (SPSS version 11.0 for Windows, SPSS, USA). Standardized data were analyzed using $\chi 2$ comparisons. Differences between two means were analyzed using unpaired Student's $t$ test. All values of $\mathrm{P}<0.05$ were considered to be significant.

\section{RESULTS}

There were $34 \mathrm{MM}$ patients $(50.7 \%)$ from the three erionite villages and 17 patients (25.4\%) from asbestos villages; 16 patients $(23.9 \%)$ came from regions with no known asbestos or erionite deposits. Fifty-one patients $(76.1 \%$ ) had pleural MM alone, 14 patients had peritoneal disease alone and two patients had both peritoneal and pleural MM. All peritoneal MM patients were male. The mean $( \pm S D)$ age of the patients was $57.6 \pm 11$ years. In the erionite-exposed group, the mean age was $53.94 \pm 13.2$ years and in the asbestos-exposed group, the mean age was $53.94 \pm 10.1$ years. Seventeen patients $(25.4 \%)$ were 20 to 49 years of age and seven patients $(10.4 \%)$ were 70 years of age and older. The ratio of male to female was 0.9 in all patients (Table 1). Asbestos and erionite exposure began at birth or early childhood in all patients from contaminated communities. In these patients, the median duration of asbestos or erionite exposure was 27 years (range 12 to 56 years), and the mean latency period (interval from first exposure to evaluation) was 45 years (range 24 to 73 years).

The most prominent symptom at presentation was dyspnea (67\%). Physical signs compatible with pleural effusion were detected in most cases (77.6\%). Lymphadenopathy was detected in nine patients (13.4\%) and subcutaneous nodules were present in 10 patients $(14.9 \%)$. On chest $\mathrm{x}$-ray, the right hemithorax was more frequently affected (58.4\%); findings are summarized in Table 2. CT examinations of the thorax were performed on 23 patients (34.3\%), and the findings are shown in Table 3.

Abdominal US was performed on 44 of 67 patients $(65.6 \%)$. The most frequently seen finding was ascites $(29.5 \%)$. Peritoneal thickening or masses were detected in two patients, and multiple peritoneal nodules were seen in one patient. US of the thyroid showed nodules in five patients, and in two patients, these nodules were shown to be MM metastases.

Methods of diagnosis of MM for all 67 patients are shown in Table 4. Needle biopsy of the pleura was the most common 
TABLE 3

Computed tomography findings in malignant mesothelioma patients $(n=23)$

\begin{tabular}{lr}
\hline Computed tomography finding & $\mathbf{n}(\%)$ \\
\hline Pleural effusion & $14(60.8)$ \\
Pleural thickening & $8(34.7)$ \\
Pleural nodule & $8(34.7)$ \\
Pleural calcification & $4(17.3)$ \\
Mediastinal invasion & $4(17.3)$ \\
Atelectasis & $3(13.0)$ \\
Parenchymal nodule & $3(13.0)$ \\
Bone (rib) invasion & $1(4.3)$ \\
Thrombosis of pulmonary artery & $1(4.3)$ \\
\hline
\end{tabular}

technique, with more invasive thoracic procedures following. Epithelial MM was present in 60 patients (89.5\%), sarcomatous $\mathrm{MM}$ in four patients $(5.9 \%)$ and mixed $\mathrm{MM}$ in three patients $(4.4 \%)$. The mean erythrocyte sedimentation rate was $43 \pm 30 \mathrm{~mm} / \mathrm{h}$ (range $26 \mathrm{~mm} / \mathrm{h}$ to $83 \mathrm{~mm} / \mathrm{h}$ ). The mean erythrocyte sedimentation rate was higher in the sarcomatous type than in the epithelial type $(\mathrm{P}<0.05 ; 68.3 \pm 7.6 \mathrm{~mm} / \mathrm{h}$ and $37.5 \pm 3.1 \mathrm{~mm} / \mathrm{h}$, respectively).

Thirty-five patients $(52.2 \%)$ were treated with chemotherapy. The regimens included ifosfamide $3 \mathrm{~g} / \mathrm{m}^{2}$ for one to three days; mesna, a uroprotective agent, $3 \mathrm{~g} / \mathrm{m}^{2}$ for one to three days every three weeks; and interferon-alpha 4.5 MU three days per week for six months as first line chemotherapy. The mean number of cycles of chemotherapy was four cycles (range one to seven cycles). The response to chemotherapy was available for 22 patients who received two or more cycles of chemotherapy. There were no complete remissions. Estimated lengths of overall survival and progression-free survival were $12 \pm 3.8$ months and $9 \pm 3.1$ months, respectively. The two-year survival rate was $22 \%$, and the two-year progression-free interval was $15.7 \%$. Pleurodesis was performed in 19 patients and pleurectomy/decortication was performed in 12 pleural MM patients. None of these patients were given chemotherapy; pleurodesis and pleurectomy/decortication were regarded as palliative treatment. There were no survival data for these patients.

\section{DISCUSSION}

MM in central Anatolia shares many features with MM in the rest of the world, but also has some unusual aspects. MM is associated with fibrous mineral exposure (10) in Anatolia, as it is elsewhere. We did not find a history of exposure to mineral fibres in 16 patients $(23.9 \%)$. In the United Kingdom, some $10 \%$ to $20 \%$ of cases of MM are apparently unrelated to mineral exposure, in that patients with no exposure history have a lung mineral content similar to that of normal control subjects (11). We recognize that our exposure data are probably underestimated, because air quality is not systematically measured, and we equated exposure with the village in which the patient lived.

In the developed world, there is a long latent interval between the first exposure to mineral fibre and the development of tumours - usually over 20 years and averaging 30 years to 40 years, which is unaffected by the age at first exposure. The
TABLE 4

Methods for diagnosis of malignant mesothelioma $(n=67)$

\begin{tabular}{lc}
\hline Methods & $\mathbf{n}(\%)$ \\
\hline Pleural biopsy & $48(71.6)$ \\
Thoracotomy & $10(14.9)$ \\
Thorascopy & $5(7.4)$ \\
Laparotomy & $3(4.4)$ \\
Lymph node biopsy & $2(2.9)$ \\
Subcutaneous nodule biopsy & $2(2.9)$ \\
Cytology & $1(1.5)$ \\
Laparoscopy & $1(1.5)$ \\
\hline
\end{tabular}

average age of MM onset is at approximately 60 years; it rarely occurs in young adults (12). The average age of our patients was 57.6 years and did not differ between the asbestos- and erioniteexposed groups. However, one-quarter of our patients were younger than 50 years of age and one was 24 years old. This high rate in younger patients was due to early onset of nonoccupational exposure to fibrous minerals.

In Australia and South Africa, MM is two to 10 times more common in men than in women $(13,14)$. This reflects the fact that asbestos exposure is occupational in these countries $(13,15)$. In our study, men and women were approximately equal in number, reflecting the fact that exposure was not related to occupation but to general air pollution. Others have noted that the prevalence of MM in women in Turkey is higher than in other countries (16-18) and approximately equal to that in men. The sex distribution of MM did not differ according to erionite or asbestos exposure.

The clinical features of MM in central Anatolia were similar to MM elsewhere. Pleural MM occurred on the right side more often, as previously described (19). As in other studies, dyspnea, cough and nonpleuritic chest pain were the most common symptoms (14). The typical presenting symptom of exudative pleural effusion was pleuritic chest pain.

Chest $\mathrm{x}$-rays showed pleural effusions in almost all of our cases (Table 2), but CT showed considerably more detail (Table 3), as others have noted (20). We detected pleural calcification in a number of patients, indicating that MM can coexist with pleural calcification. MM must be considered in the differential diagnosis when unilateral effusion accompanies pleural calcification. Extrathoracic metastasis is unusual in MM (21). In the present study, peritoneal dissemination and thyroid gland metastasis were identified by US examination. As in other studies (1), we found that pleural biopsy by needle was the most useful technique for the pathological diagnosis of MM (71.6\%). Cytological examination had much less diagnostic value, in agreement with others $(3,22)$.

Pathological subtype distribution has been previously reported to be: epithelial, $25 \%$ to $81 \%$; mixed, $0 \%$ to $66 \%$; and sarcomatous, $4 \%$ to $32 \%$ (23). In the present study, the distribution was similar: epithelial in 60 patients $(89.5 \%)$, sarcomatous in four patients $(5.9 \%)$ and mixed in three patients $(4.4 \%)$. There was no difference in histological subtypes between those exposed to asbestos or erionite. 
MM is a disease with a bleak prognosis, and it is unclear whether any therapeutic intervention has had a significant impact on more than a few highly selected patients. A median survival period of six to 18 months is usually quoted (24), and our data agree with this. Although nearly every class of cytotoxic agent has been evaluated in patients with mesothelioma, response rates of greater than $20 \%$ have not been consistently demonstrated for any single drug. In our patients, chemotherapy did not induce any remissions, and the two-year survival rate was $22 \%$ in patients who received chemotherapy.

Erionite as a cause of MM may be unique to Central Anatolia. Erionite belongs to the mineralogical group of zeolites. It is a complex mixture of hydrated aluminosilicates of alkali and alkaline earths, including approximately 40 natural minerals. It typically occurs in cavities of volcanic rocks and other late-stage hydrothermal environments. It is a more potent carcinogen than crocidolite, the most dangerous form of asbestos (25). Zeolites have a very large internal surface area resulting from the particular configuration of their crystalline lattice. They are able to lose or gain water molecules and to exchange cations without major changes to their crystalline structure; they also have catalytic activity. The physical and chemical characteristics of erionite may explain its greater

\section{REFERENCES}

1. Baris YI. Asbestos and Erionite Related Chest Diseases, 1st edn. Ankara: Semih Ofset Mat Ltd Co, 1987:1-67.

2. Baris YI, Saracci R, Simonato L, Skidmore JW, Artvinli M. Malignant mesothelioma and radiological chest anormalities in two villages in Central Turkey. An epidemiological and environmental investigation. Lancet 1981;i:984-7.

3. Topcu F, Bayram H, Simsek M, et al. High-resolution computed tomography in cases with environmental exposure to asbestos in Turkey. Respiration 2000;67:139-45.

4. Gibbs AR. Role of asbestos and other fibres in the development of diffuse malignant mesothelioma. Thorax 1990;45:649-54.

5. Ozesmi M, Artvinli M, Baris YI, Kolaçan B, Goktepeli A. Prevalence of pleural calcification related with silica in asbestos region of Mihaliccik. J Tuberc Thorax 1974;22:487-96.

6. Baris YI, Simonato L, Artvinli M, Pooley F, Saracci R, Skidmore J. Epidemiological and environmental evidence of the health effects of exposure to erionite fibers: A four-year study in the Cappadocian region of Turkey. Int J Cancer 1987;39:10-7

7. McDonald AD, Harper A, McDonald JC, el Attar OA. Epidemiology of primary malignant mesothelial tumours in Canada. Cancer 1970;26:914-9.

8. McDonald AD, Case BW, Churg A, et al. Mesothelioma in Quebec chrysotile miners and millers: Epidemiology and aetiology. Ann Occup Hyg 1997;41:707-19.

9. Yazicioglu S, Ilcayto R, Balci K. Endemic mesothelioma and pleural calcification related with environmental asbestos exposure in Southeast Anatolia. Cerrahpasa Med J 1980;11:354-61.

10. Enterline PE. Role of manmade mineral fibres in the causation of cancer. Br J Ind Med 1990;47:145-6.

11. Pelnar PV. Further evidence of non-asbestos related mesothelioma. Scand J Work Environ Health 1988;14:141-4.

12. Peto J, Seidman H, Selikoff IJ. Mesothelioma mortality in asbestos workers: Implications for models of carcinogenesis and risk assessment. Br J Cancer 1982;45:124-35.

13. Ferguson D, Berry G, Jelihovski T, Andreas S, Rogers A, Fung SC. The Australian Mesothelioma Surveillance Program 1979-85. Med J Aust 1987;147:166-72. carcinogenecity compared with asbestos. Erionite has a hexagonal structure with an internal surface of $200 \mathrm{~m}^{2} / \mathrm{g}$, which is 20 times larger than that of crocidolite asbestos; this allows it to adsorb small molecules and have a high catalytic activity (26). Erionite induces more reactive oxygen-free radicals than asbestos and glass fibres (27). A recent study showed that Turkish erionite fibers differ in their physical and chemical properties compared with the reference erionite from Jersey Valley, Nevada, USA. The magnesium content of erionite from air and lung tissue specimens from the Tuzkoy region of Turkey was higher than that found in California, USA. It was suggested that there could be a link between the magnesium content and carcinogenicity of Turkish erionite (28).

\section{CONCLUSIONS}

$\mathrm{MM}$ is one of the major health problems in Turkey. MM in Central Anatolia differs from that in other parts of the world. It is common and is caused by environmental, as opposed to occupational, exposure. The outcome of the disease in Anatolia is similar that reported elsewhere. Though improvements in diagnosis and therapy would be welcome, the most important issue is to identify sources of asbestos and erionite fibres, and to prevent further exposures.

14. Zwi AB, Reid G, Landau SP, Kielkowski D, Sitas P, Becklake MR. Mesothelioma in South Africa, 1976-84: Incidence and case characteristics. Int J Epidemiol 1989;18:320-9.

15. Boutin C, Schlesser M, Frenay C, Astoul M. Malignant pleural mesothelioma. Eur Respir J 1998;12:972-81.

16. Selcuk ZT, Coplu L, Emri S, Kalyoncu AF, Sahin AA, Baris YI. Malignant pleural mesothelioma due to environmental mineral fiber exposure in Turkey. Analysis of 135 cases. Chest 1992;102:790-6.

17. Senyigit $A$, Babayigit $C$, Gokirmak $M$, et al. Incidence of malignant pleural mesothelioma due to environmental asbestos fiber exposure in the southeast of Turkey. Respiration 2000;67:610-4.

18. Metintas M, Hillerdal G, Metintas S. Malignant mesothelioma due to environmental exposure to erionite: Follow-up of a Turkish emigrant cohort. Eur Respir J 1999;13:523-6.

19. Hillerdal G. Malignant mesothelioma 1982: Review of 4710 published cases. Br J Dis Chest 1983;77:321-43.

20. Isik R, Simsek M, Coskunsel M, Bukte Y. CT findings in diagnosis of malignant mesothelioma. Tuberc Thorax 1993;41:45-50.

21. Miller WT Jr, Gefter WB, Miller WT Sr. Asbestos-related chest disease: Plain radiographic findings. Semin Roentgenol 1992;27:102-20.

22. Hillerdal G, Ozesmi M. Benign asbestos pleural effusion: 73 exudates in 60 patient. Eur J Respir Dis 1987;71:113-21.

23. Neumann V, Gunthe S, Mulle KM, Fischer M. Malignant mesothelioma - German mesothelioma register 1987-1999. Int Arch Occup Environ Health 2001;74:383-95.

24. Kindler HL. Malignant pleural mesothelioma. Curr Treat Options Oncol 2000;1:313-26.

25. Robinson BWS, Chahinian AP, eds. Mesothelioma. London: Martin Dunitz Ltd, 2002:344.

26. Baris Y. Fibrous zeolite (erionite)-related diseases in Turkey. Am J Ind Med 1991;19:374-8.

27. Maples KR, Johnson NF. Fiber-induced hydroxyl radical formation: Correlation with mesothelioma induction in rats and humans. Carcinogenesis 1992;13:2035-9.

28. Emri S, Demir A, Dogan M, et al. Lung diseases due to environmental exposures to erionite and asbestos in Turkey. Toxicol Lett 2002;127:251-7. 


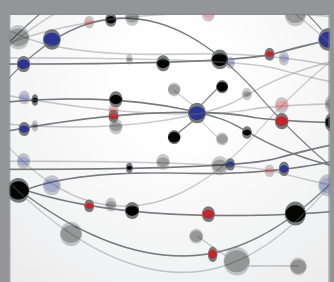

The Scientific World Journal
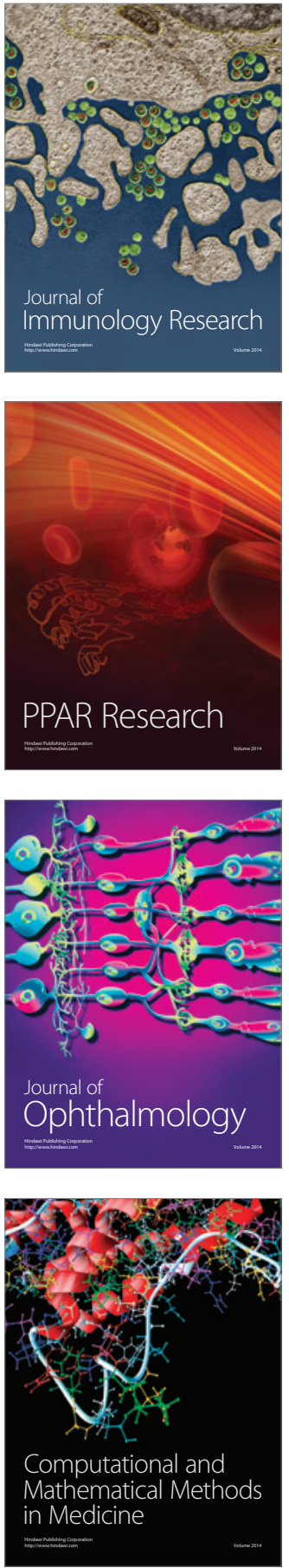

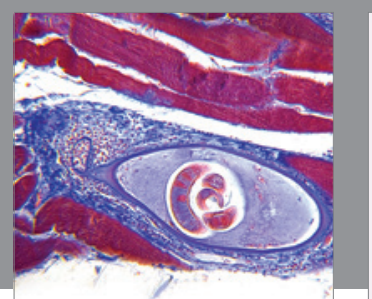

Gastroenterology Research and Practice

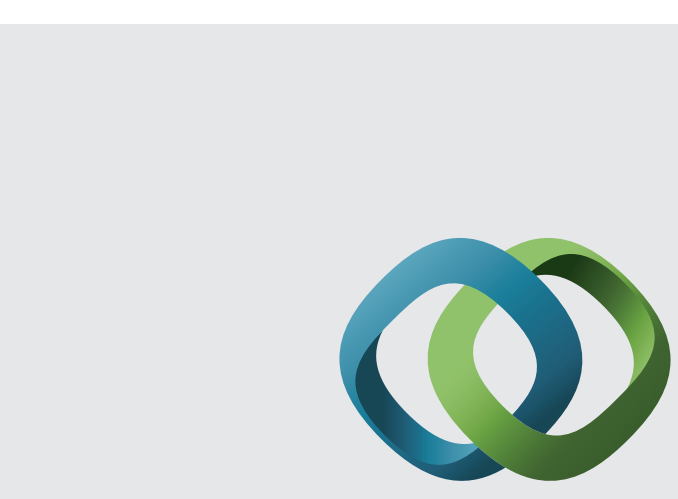

\section{Hindawi}

Submit your manuscripts at

http://www.hindawi.com
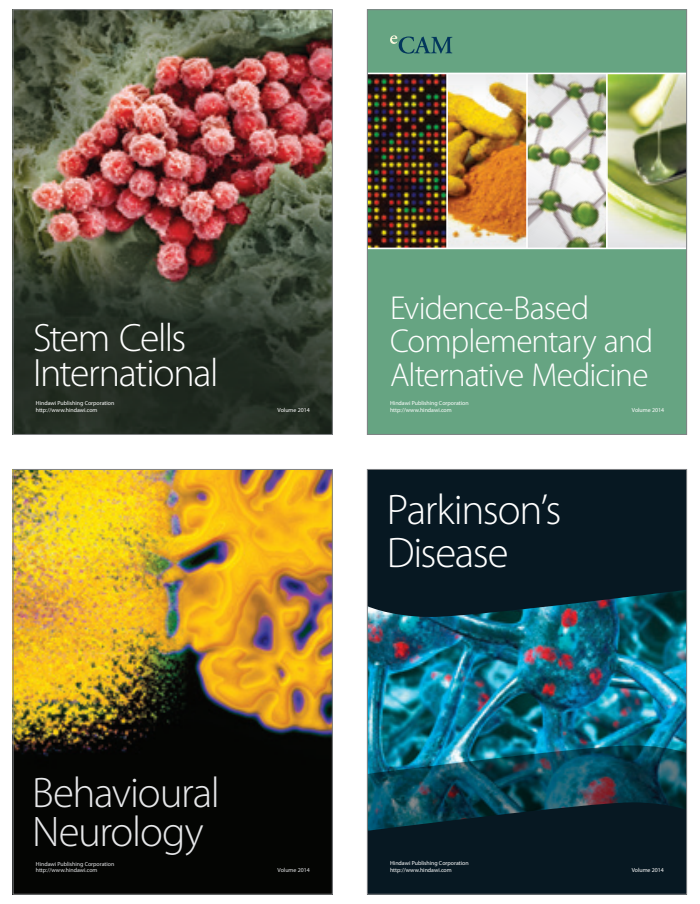
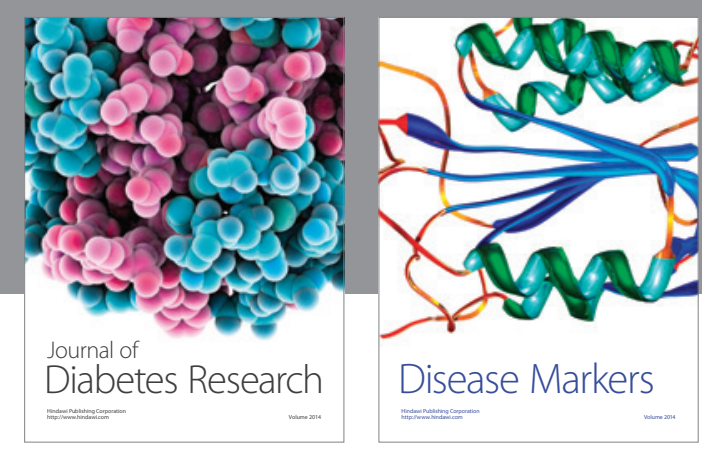

Disease Markers
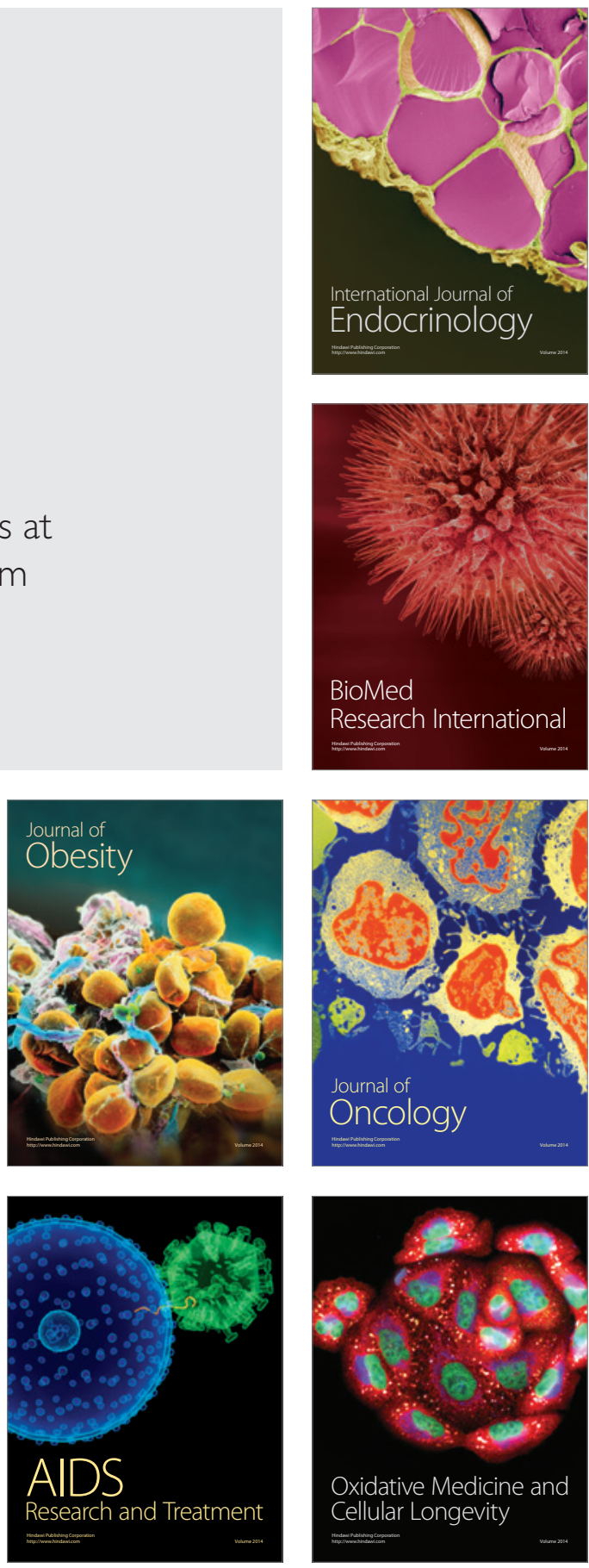